\title{
RECENT DECISIONS UNDER THE EVARTS ACT.
}

By Roger Foster, OF THE NEW YORK BaR.

As originally blocked out by its author, the Evarts Act, creating the new Circuit Courts of Appeals of the United States, was simple in form, and its construction and application would have given little difficulty to the bench and bar. A number of amendments were proposed by senators, who did not understand its full scope, and in at least one instance, the amendment proposed by Senator Daniels of Virginia concerning the review by the Supreme Court of criminal cases, radically changing the original intention of the act. It was the belief of Senator Evarts and the Justices of the Supreme Court, that it was of more importance that some act should then be passed creating new Courts of Appeal, and affording a frame within which harmony could subsequently be produced by appropriate amendments, than to await the passage of a perfect act at some indefinite time in the future. Immediate relief for the Supreme Court, which was many years behind its constantly increasing docket, was' imperatively demanded. For that reason Senator Evarts assented to the incorporation of any amendment proposed either in the judiciary committee or in the Senate, his opposition to which might endanger the passage of the bill before the adjournment of Congress. Consequently the act is unusually obscure. This article contains merely an abstract of the decisions hitherto reported, which throw light upon the construction of the statute. It is not the intention of the author to hazard any opinion of his upon points not hitherto adjudicated.

The act took effect immediately upon its approval, March 3, r89r. $a$ From that time the Supreme Court of the United States had jurisdiction to review any judgment or decree previously entered, involving questions to which the act extended its jurisdiction, unless the statutory time to appeal had expired. $b$ In a case

$a$ In re Claasen, r40 U. S. 200.

$b$ In re Claasen, I40 U. S. 200. 
where, before the passage of the act, the plaintiff in error had lost his right to a bill of exceptions, the act did not revive such right, although it gave him a writ of error.c While the Circuit Courts of Appeals had no power to organize before the third Tuesday of January, $18{ }_{9} \mathrm{x}, d$ after their organization they have the right to review judgments entered after the decision of the Evarts Act, March 3, r891, and before their organization.e A Circuit Court

$c$ In re Claasen, 140 U. S. 200.

d 26 St. at L. p.

$e$ The Northern Pacific Railroad Co. $v$. Amato, U. S. Circuit Court of Appeals, Second Circuit, January I9, I892. On account of the importance of this case, which has not yet been reported, except in the New York Law Jour$n a l$, it is published herewith in full.

" United States Circuit Court of Appeals ; for the second circuit, January 1892. The Northern Pacific Railroad Company, plaintiff in error, $u$. Dominick Amato, defendant in error. In November, 1888, Amato, the defendant in error, who was a laborer on the railroad of the plaintiff in error, was run over and his leg cut off by one of the company's locomotives. He had been at work, with a gang of fifty-six, near the west end of the railroad bridge at Bismarck, in North Dakota. They lived near the east end of the bridge, and it was the custom of the company to take the men home from their work, on a car drawn by a locomotive, about half-past five each afterncon. On the day of the accident, however, the boss told them there would be no train to take them across, and that they would have to walk. He further told them that no engine would come over the bridge until about seven or half-past seven. They all started to walk across, but Amato, in consequence of a pain in his side, could not keep up with the others, and fell behind, walking by himself. There was but one track on the bridge and on that track he walked. There was not room to walk at the side of the track without crawling from one trestle to another. An engine came on the bridge from the east, meeting him about midway across. From the place where he met the engine to the east end was about 700 feet, and the track straight. There was room on the bridge to allow him to step aside and let the engine pass, if he had seen it coming. He did not see it, until it was "on top of him," then he tried to get out of the way, but slipped on the track, which was slightly frozen, fell and caught his leg under the wheel of the engine which passed over it, culting it off. The action was commenced in February, I8go, and was tried in the Circuit Court for the Southern District of New York, April r7, I89r, resulting in a verdict for $\$ 4, \infty 00$ in favor of the plaintiff below. Judgment was entered May 28, r8gr, and the bill of exceptions was signed July I6, I89r. A writ of error to this Court was issued from the clerk's office of the Circuit Court on July 27, I8gr. Henry Stanton for Northern Pacific Railroad Company, plaintiff in error; Roger Foster for Dominick Amato, defendant in error.

"LACOMBE, J.-The defendant in error contends that the writ of error is void, because it was issued from the Circuit Court, and not from the Circuit Court of Appeals. Such contention is unsound. The act of March 3, r8gr, establishing the Circuit Court of Appeals (26 U. S. Stat. at Large, 5I7) provides in its eleventh section that ' all provisions of law in force (when the act was passed) regulating the methods and system of review through appeals or writs 
of Appeals has jurisdiction to review a judgment of a District or Circuit Court, otherwise within its appellate jurisdiction, no

of error, shall regulate the methods and system of appeals and writs of error provided for in this act in respect to the Circuit Court of Appeals.' At the time the act was passed it was provided by section 1004 of the U. S. Revised Statutes that " writs of error returnable to the Supreme Court may be issued as well by the clerks of the Circuit Courts, under the seals thereof, as by the clerk of the Supreme Court.' By the eleventh section (above quoted) this regulation touching the method of review by writ of error was extended to cases returnable to the new courts of review.

"It is also urged on behalf of the defendant in error that no writ of error lies in review of this judgment, inasmuch as the matters in dispute, exclusive of costs, is less than $\$ 5,000$. Reference is made to the eleventh section of the act establishing the Courts of Appeals (above quoted) and to the provisions of the U. S. Revised Statutes $(\S 69 \mathrm{I})$ limiting the jurisdiction of the Supreme Court to cases involving that amount. The difficulty with this argument is that the very act which created the new courts expressly repealed section $6 \mathrm{gr}$ of the Revised Statutes and also section three of the earlier act of February I6, 1875, limiting the jurisdiction to cases involving $\$ 2,000$ (act of March 3, I89r, $\S \mathrm{I4}$ ). At the time the new act was passed these provisions as to the amount in controversy ceased to exist, and were, therefore, not transferred to the new courts as 'provisions of law (then) in force.'

"Defendant in error further contends that this Court has no jurisdiction to review, by writ of error, a judgment which was entered before the day prescribed in the joint resolution of March 3 , I8gr, for the organization of this Court; and that this action is not affected by the act of March 3, x8gr, having been begun before its passage, and therefore within the saving clause of the joint resolution which provides that 'said act shall not in any wise * * impair the jurisdiction of any court of the United States in any case now pending before it.' It is argued that the jurisdiction of the Circuit Court would be impaired if, in a case where its judgments were formerly absolute, they may now be reversed by writ of error. This point, however, has been disposed of by the Supreme Court In re Claasen (140 U. S. 200), where a writ of error was allowed, under the new act, to review a final judgment rendered March 18 , 18gr, in a criminal action pending before the passage of the act, and which judgment was not (except for such act) reviewable by writ of error ; the court holding that the act of March 3, I8gr, went into immediate operation so as to permit a writ of error in such a case. The new courts were created by the act $(\$ 2)$ which took effect upon its passage, not by the joint resolution, which merely provided for their first meeting day.

. Defendant in error further contends that the bill of exceptions cannot be considered because it was allowed too late, judgment having been entered May 28th and the bill of exceptions allowed July 16th, and refers to Circuit Court Rules 67 and 69 (for Southern District of New York). These rules provide as follows :

"(a). Exceptions shall be drawn up and served before judgment is rendered and entered (unless the time shall be enlarged by a judge).

"(b). Amendments thereto are to be served within four days after service of the exceptions (unless the time shall be so enlarged). 
matter how small may be the value of the subject matter in dispute. $f$

The-Supreme-Court of the United States has iurisdiction to review by writ of error any judgment of a District or Circuit Court in a criminal case in which the plaintiff in error has been sentenced to death or to imprisonment in a State prison or penitentiary with or without hard labor. $g$

It was suggested by Mr. Russell $\mathrm{H}$. Curtis in his valuable annotated edition of the Evarts Act that inasmuch as the Evarts Act gives the Supreme Court jurisdiction "in any case in which the jurisdiction of the court is in issue, in which case the question of jurisdiction alone must be certified to the Supreme Court from the court below for decision, a question of jurisdiction might be certified to the Supreme Court by the court below before the final judgment in the case; that proceedings would then be suspended until the determination of the question certified by the Supreme Court ; and that if the Supreme Court sustained the jurisdiction,

“(c). Four days are allowed for the parties to agree (unless the time shall be so enlarged)

“(d). If they cannot agree, four day's notice of settlement may be given by either party (unless the time be so enlarged).

"(e). The judge shall thereupon correct and settle the same-within what time the rules do not prescribe.

"There is nothing in these rules requiring the exceptions to be settled and filed before judgment, and, for all that appears in the record before us, the proposed exceptions were drawn up and served before judgment, as the rules require.

"The plaintiff in error insists that the trial judge erred in not taking the case from the jury and directing a verdict for the company, because, as it contends, the undisputed testimony showed that Amato was guilty of culpable negligence, which brought about the accident. He testified that 'he was walking at his ease, not thinking of anything,' did not see the engine when it came on the straight part of the bridge; but also stated that he 'never thought of it,' for the reason that the boss told him there was 'nothing to come across.' We are of the opinion that it was fairly a question for the jury to determine whether or not it was negligence on his part not to keep a look out for a coming engine in view of the boss' assurance that there was none to come. The case is quite within the decisions in Bradley $v$. N.Y. Central R. R. (62 N. Y. 99); and Oldenbarg v. N. Y. C. \& H. R. R. R. (43 Alb. L. J. 362).

"The judgment of the Circuit Court is affirmed, with costs of this appeal.

"Wallace, J., concurs."

Mr. Justice Brown has informed the author that in an unreported case not named by him, he concurred with Judge Jackson and Judge Sage in the Sixth Circuit, in holding both this point and the point next stated, decided in The Northern Pacific Railroad Co. $v$. Amato.

$f$ The Northern Pacific Railroad Co. v. Amato, supra.

$g$ In re Claasen I40 U. S. 200, 205. 
the case might proceed to a subsequent decision by the court below and a subsequent review by the Circuit Court of Appeals. This suggestion has been rejected by the Supreme Court of the United States, which held, speaking through Mr. Justice Lamar, in a recent important case:

"Does this provision authorize an appeal or writ of error to be taken to this court for review of a question involving the jurisdiction of the court below whenever it arises in the progress of a case pending therein ; and does the taking of such appeal or writ of error operate to stay the further proceedings in the case until the determination by this court of the jurisdictional question ? Or, in other words, has this court jurisdiction to review the question before any final judgment in the cause? The plaintiff in error contends that we have the jurisdiction to review such question, because ( $I$ ) there is in the section above quoted no express requirement of finality of judgment; and (2) because there is a positive requirement that the question of jurisdiction shall alone be certified to the Supreme Court from the court below for decision. It is further argued that the omission of the word final in this particular provision, and the repeated use of that word in other sections of the act, in reference to a different class of cases, show the intent of the act to be that the review of the question of jurisdiction should not await the final determination of the case in the court below. We think that upon the principles of construction such is not the meaning of the act of Congress under consideration. It is manifest that the words in $\S 5$, 'appeals or writs of error,' must be understood within the meaning of those terms as used in all prior acts of Congress relating to the appellate powers of this court, and in the long standing rules of practice and procedure in the Federal courts. Taken in that sense those terms mean the proceedings by which a cause, in which there has been a final judgment, is removed from a court below to an appellate court for review, reversal or affirmance. It is true that the Judiciary Act of 1789 limited the appellate jurisdiction of this court to final judgments and decrees, in the cases specified. This, however, in respect to writs of error was only declaratory of a well settled and ancient rule of English practice. At common law no writ of error could be brought except on a final judgment. Bac. Ab. Error A. 2, "If the writ of error be returnable before judgment is given, it may be quashed on motion.' 2 Tidd's Practice, II62. In respect to appeals there is a difference in the practice of the English chancery courts, in which appeals may be taken from an interlocutory order of the Chancellor of the House of Lords, and the practice of the United States chancery courts, where the right of appeal is by statute restricted to final decrees, so that a case cannot be brought to this court in fragments. From the very foundation of our judicial system the object and policy of the acts of Congress in reiation to appeals and writs of error, (with the single exception of a provision in the act of 1875 in relation to cases of removal, which was repealed by the act of 1887 ), have been to save the expense and delays of repeated appeals in the same suit, and to have the whole case and every matter in controversy in it decided in a single appeal. Forgay $\nu$. Conrad, 6 How. 201, 204. The construction contended for would render the act under consideration inconsistent with this long established object and policy. More than this, it would defeat the very object for which that act was passed. It is a matter of public history, and is manifest on the face of that act, that its primary object was to facilitate the prompt disposition of cases in the Supreme Court, and to relieve 
it of the enormous overburden of suits and cases resulting from the rapid growth of the country and the steady increase of its litigations. That act, in substance, creates a new and distinct Circuit Court of Appeals, in each circuit, to be composed of three judges, namely, the circuit justice, when present, and two circuit judges, and also, in the absence of any one of those three, a district judge selected by assignment for the purpose of completing the court. It then provides for the distribution of the entire appellate jurisdiction of our national judicial system, between the Supreme Court of the United States and the Circuit Court of Appeals, therein established, by designating the classes of cases in respect of which each of those two courts shall respectively have final jurisdiction. But as to the mode and manner in which these revisory powers may be invoked, there is, we think, no provision in the act which can be construed into so radical a change in all the existing statutes and settled rules of practice and procedure of Federal courts as to extend the jurisdiction of the Supreme Court to the review of jurisdictional cases in advance of the final judgments upon them. But there is an additional reason why the omission of the word final, in the fifth section of the act should not be held to imply that the purpose of the act is to extend the right of appeal to any question of jurisdiction, in advance of the final judgment, at any time it may arise in the progress of the cause in the court below. Such implication if tenable, cannot be restricted to questions of jurisdiction alone. It applies equally to cases that involve the construction or application of the Constitution of the United States; and to cases in which the constitutionality of any law of the United States or the validity or construction of any treaty made under its authority, is drawn in question ; and to those in which the constitution or law of a State is claimed to be in contravention of the Constitution of the United States. Under such a construction all these most important classes of cases could be directly taken by writ of error or appeal, as the case may be, to this court, independently of any final judgment upon them. The effect of such a construction, if sanctioned, would subject this court to the needless delays and labor of several successive appeals in the same case, which, with all the matters in controversy in it, by awaiting the final judgment. could be promptly decided in one appeal. It is also insisted that $\S x_{4}$ of the act in question, repealing $\S 69 \mathrm{x}$ of the revised statutes and $\S 3$ of the act of February 16,1875 , gives a wider scope to the revisory powers of this court, and makes a final judgment unnecessary to the exercise of these powers in the cases specified in said fifth section. We think that that repeal applies, in both sections mentioned, only to the provisions which limit the appellate power of the Supreme Court to cases involving the amounts there respectively specified namely, $\$ 2000$ in one and $\$ 5000$ in the other. If it was the purpose of the act to repeal that part of those sections which refers to final judgments, such intention would have been indicated in express and explicit terms, inasmuch as there were, when the act was passed, other sections and other statutes containing the same limitation of appeals to final judgments. It is further argued, in support of the contention of the plaintiff in error, that if it should be held that a writ of error would not lie upon a question of jurisdiction until after final judgment, such ruling would lead to confusion and absurd consequences ; that the question of jurisdiction would be certified to this court, while the case on its merits would be certified to the Circuit Court of Appeals ; that the case would be before two separate appellate courts at one and the same time; and that the Supreme Court might dismiss the suit upon the question of jurisdiction while the Circuit Court of Appeals might 
properly affirm the judgment of the lower court upon the merits. The fallacy which underlies this argument is the assumption that the act of I8gI contemplates several separate appeals in the same case and at the same time to two appellate courts. No such provision can be found in the act, either in express terms or by implication. The true purpose of the act, as gathered from its context, is that the writ of error, or the appeal, may be taken only after final judgment, except in the cases specified in $\S 7$ of the act. When that judgment is rendered, the party against whom it is rendered must elect whether he will take bis writ of error or appeal to the Supreme Court upon the question of jurisdiction alone, or to the Circuit Court of Appeals upon the whole case ; if the latter, then the Circuit Court of Appeals may, if it deem proper, certify the question of jurisdiction to this Court." $h$

As a logical result of this decision, the Supreme Court has held that an order remanding a case from a Federal to a State Court after a removal, cannot now he reviewed by the Supreme Court by a writ of error to, or appeal from such order of remand. $i$

In but a single reported case has the Supreme Court directed a Circuit Court of Appeals to certify to it for decision a case in which the Circuit Court of Appeals had final jurisdiction. It was there held that the question whether the Chinese restriction acts, in the light of the treaties between the United States and China, apply to a Chinese merchant, domiciled in the United States, who temporarily leaves the country for the purpose of business or pleasure, with the intention to return, is a question of sufficient gravity and importance to warrant an order for a writ of certiorari requiring the Circuit Court of Appeals to certify it to the Supreme Court for review and determination. $j$

A writ of certiorari was then ordered after final judgment of the Circuit Court of Appeals, and after the Circuit Court of Appeals had refused to certify the main order in question in the the case to the Supreme Court, Chief Justice Fuller said:

"It is evident that it is solely questions of gravity and importance that the Circuit Courts of Appeals should certify to us for instruction; and that it is only when such questions are involved that the power of this court to require a case in which the judgment and decree of the Court of Appeals is made final to be certified, can be properly invoked. The inquiry upon this application, therefore, is whether the matter is of sufficient importance in itself, and sufficiently open to controversy, to make it the duty of this court to issue the writ applied for in order that the case may be reviewed and determined as if brought here on appeal or writ of error. Assuming for the purposes of the present motion, that the Court of Appeals had jurisdiction, it will be perceived

h Mr. Justice Lamar, in McLish $v$. Rpff, I4I U. S. 66r, 664-668.

$i$ Chicago, St. Paul, Minneapolis and Omaha Railway Co. $v$. Roberts, I4I U. S. 6 go.

$j$ Lau Ow Bew, Petitioner I4I U. S. 583 . 
from what has been stated that the disposition of the case involves the application of the Chinese restriction acts to Chinese merchants domiciled in the United States who temporarily leave the country for purposes of business or pleasure, animo revertendi, in the light of the treaties between the government of the United States and that of China. By the treaty between the United States and China of $\mathrm{r868}$, all Chinese subjects were guaranteed the right, without conditions or restrictions, to come, remain in, and leave the United States, and to enjoy all the privileges, immunities and exemptions enjoyed by the citizens of the most favored nation. 16 Stat. 740, Art. vi. The treaty of November I7, r880, put no limitation upon this right, so fai as Chnese other than laborers were concerned. 22 Stat. 826. To what extent was any limitation intended by the acts of 1882 and 1884 , drawn into consideration here, bearing in mind the general rule that repeals by implication are not favored? The sixth section of the act of 1882, as amended by the act of I884, 22 Stat. 58, 23 Stat. II5, provided that 'every Chinese person, other than a laborer who may be entitled by said treaty or this act to come within the United States, and who shall be about to come to the United States, shall obtain the permission of and be identified as so entitled,' in the mode stated, and the certificate therein provided for is made the sole evidence, as to those to whom the section is applicable, to establish a right of entry into the United States. Manifestly the question whether this section should be construed, taken with the treaties, to apply to Chinese merchants already domiciled in the United States, and to whom no intention of voluntarily surrendering that domicile can be imputed, is one of great gravity and importance. The status of domicile in respect of natives of one country domiciled in another is a matter of international concern, and the acts of Congress are to be considered, in view of general and settled principles upon that subject, in arriving at a conclusion as to the operation upon the treaties with China, designed by Congress in those enactments. Was it intended that commercial domicile should be forfeited by temporary absence at the domicile of origin, and to subject resident merchants to loss of rights guaranteed by treaty if they failed to produce from the domicile of origin that evidence which residence in the domicile of choice may have rendered it difficult, if not impossible to obtain? We refrain from particular examination of the point involved, and refer to it only so far as necessary to indicate its importance." $k$

He further said that " this branch of our jurisdiction should be exercised sparingly and with great caution." $l$

A justice of the Supreme Court has power to grant a supersedeas or stay of proceedings in a criminal case, the judgment in which, the Supreme Court has jurisdiction to review. As no security is required in a criminal case, the supersedeas may be obtained by merely serving the writ of error, within the time prescribed by law, without any security, provided the justice who signs the citation directs in writing that the writ shall operate as a

$k$ Lau Ow Bew, Petitioner, I4I U. S. $583,587,588$.

$l$ Lau Ow Bew, Petitioner, I4I U. S. 583, 589. 
supersedeas, which he may do with or without security in his discretion. $m$

A writ of error from a Circuit Court of Appeals for the review of the judgment of a Circuit Court may issue from the clerk's office of such Circuit Court, under the seal of such Circuit Court and the signature of the clerk thereof; and need not bear the seal or signature of the Clerk of the Circuit Court of Appeals. $n$ No execution can issue upon any judgment of the Circuit Court, which may be reviewed by the Supreme Court, or by the Circuit Court of Appeals, until ten days after the entry of such judgment. 0

It is the practice in the Second Circuit, upon the filing of its opinion by the Circuit Court of Appeals, for the successful party to enter an order for the issue of a mandate thereupon. He must tax in the Circuit Court of Appeals, before the issue of such mandate, his costs which are included in such mandate. The costs are a docket fee of twenty dollars; the disbursements for printing and filing briefs, and for a copy of the opinion of the Circuit Court of Appeals; and all fees, past or prospective, of the clerk of the Circuit Court of Appeals, as well as the notarial fees for affidavits necessarily made for use in such Circuit Court of Appeals. After the taxation of the costs, the mandate issues to the Circuit or District Court, in the Clerk's office of which it is filed. An order must then be entered directing judgment in accordance with the mandate, which judgment will include, after their taxation, such disbursements as have been made or incurred in the Circuit Court since the entry of the judgment or decree reviewed by the writ of error or appeal. It has been held in the Second Circuit that the act of February 16,1875 , which required the Circuit Court to make findings of fact and conclusions of law in admiralty, and provided that the Supreme Court should not review a finding of fact on conflicting evidence does not apply to the Circuit Courts of Appeals. $p$

The Supreme Court has pending before it, argued but not decided, the question whether appeals from decisions upon applications for the writ of habeas corpus are regulated by the Evarts Act or by the former practice. In the Chinese case just cited, the Supreme Court ordered such a case, which had been decided by the

$m$ In re Claasen, I40 U. S. 200, 208.

$n$ The Northern Pacific Railroad Co. v. Amato, supra.

$\circ$ U.S. R. S. Section roo7; Amato u. The.Northern Pacific Railroad Co., U. S. C. C. S. D. N. Y., July 17, I8gr, decided by Judge Lacombe, without any opinion.

p The Avilah, N. Y. Law Journal, Nov. 4, 189I ; S. C. I. Arc. App. I. 
Circuit Court of Appeals, to be certified to it without questioning the jurisdiction of the Circuit Court of Appeals. In another important case, $q$ the Supreme Court took jurisdiction of an appeal from an order of a Circuit Court discharging a writ of habeas corpus and remanding the prisoner to custody, on the ground that since the constitutionality of a statute was disputed the case involved the constitutionality of a law of the United States.

A curious question arising from an obscure passage in the Evarts Act is pending in, but not yet argued before, the Supreme Court. Section 6, provides that "The judgments or decrees of the Circuit Courts of Appeals shall be final in all cases in which the jurisdiction depends entirely upon the opposite parties to the suit or controversy being aliens and citizens of the United States, or citizens of different States; also in all cases arising under the patent laws, under the revenue laws, under the criminal laws, and in admiralty cases," unless the question is certified by the Circuit. Court of Appeals to the Supreme Court, or the Supreme Court directs the whole case to be certified to it for review. That section concludes, "In all cases not hereinbefore in this section made final, there shall be of right an appeal or writ of error, or review of the case by the Supreme Court of the United States, where the matter in controversy exceeds one thousand dollars besides costs." In a case $r$ begun in the Supreme Court of the State of New York against a corporation chartered by an act of Congress and removed by the defendant to the Circuit Court of the United States, upon the ground that on account of its incorporation, the case was one arising under the laws of the United States; after judgment against it in the Circuit Court, a writ of error argued before the Circuit Court of Appeals, an order for a mandate of affirmance, and the filing of such mandate in the Circuit Court, the defendant applied for a writ of error to the order of the Circuit Court of Appeals, returnable to the Supreme Court of the United States, upon the ground that, inasmuch as the case was not one in which the judgment of the Circuit Court of Appeals was final, since the jurisdiction of the Federal Courts was not dependent entirely upon the fact that the plaintiff was an alien and the defendant a citizen of the United States, he was entitled to a review of the judgment of the Circuit Court of Appeals by a second writ of error. If this contention should be sustained by the Supreme Court, it would seem to follow that in all cases either on contract or tort against

$q$ Lau Ow Bew, Petitioner, I4I U. S. 583.

$r$ Ekin $v$. U. S. Supreme Court, Jan. 18, 1892. 
the Northern Pacific, the Union Pacific, the Southern Pacific, and other railway companies, incorporated by Congress, and all national banks, the corporation has a right to a double review by appeal or writ of error, if the value of the matter in dispute exceeds one thousand dollars.

As the point is in litigation, no opinion on it is now expressed; but it seems not improper to say that if this construction is sustained cases of that character, together with criminal cases, will so fill the docket of the Supreme Court of the United States, that the Evarts act will be found rather to increase than to diminish the labors of that tribunal. 